\title{
Interferon-Induced Protein 44
}

National Cancer Institute

\section{Source}

National Cancer Institute. Interferon-Induced Protein 44. NCI Thesaurus. Code C123868.

Interferon-induced protein 44 (444 aa, $\sim 50 \mathrm{kDa}$ ) is encoded by the human IFI44 gene.

This protein may play a role in interferon-dependent processes. 